\title{
Tax Revenue Productivity on Nepalese Economy
}

\author{
Binod Sah, PhD \\ Lecturer \\ Central Department of Management, Kathmandu, Tribhuvan University, Nepal \\ Email: binod.cdm@gmail.com
}

DOI: https://doi.org/10.3126/dristikon.v10i1.34539

\begin{abstract}
This paper seeks to examine the productivity of Tax Revenue (TR) in the Nepalese economy. It, therefore, analyzes the impact of TR on GDP in aggregate level. This study adopts explanatory research design and attempts to determine the relationship between TR and the GDP. Exchange rate, market capitalization money supply and government spending being the intervening variables included in the model. In order for the specification of a model of cointegrated regression model with a time series data of the variables are employed for the study period of 20 years, from 1999/2000 to 2018/19. The values of all the variables are converted into real price (constant price) by GDP deflator. The GDP deflator and CPI year 2013/14 have been assumed equivalent to the base year 2013/14 according to Nepalese fiscal year. Since it is observed that residuals are not normally distributed, autocorrelation and multi-collinearity problem in the model, it is necessary to improve the non-normal distribution, autocorrelation and multi-collinearity problem in the model. Therefore, the data are transposed into first difference and run the model with error correction model $\left(\mathrm{ECM}_{\mathrm{t}-1}\right)$. The $\mathrm{R}^{2}$ shows that the explanatory power of the model, indicating that the variation of GDP is explained to the extent of 81 percent variation of the independent variable included in the model. The estimated coefficient of TR in error correction model shows that one percent point rise in TR has led to 0.17645 percent point increase in real GDP in short run, whereas it is found 0.21364 percent point in the long-run. This is supported by (World bank, 2003, 2007, 2018) using a large sample of developing countries observed over the period 1980-2006, and even after factoring in the endogeneity of tax revenue.
\end{abstract}

Keywords: productivity, GDP, tax revenue, exchange rate, market capitalization

\section{Introduction}

\section{Background}

Economic development in Nepal has been complicated and affected by the constant change in political scenarios which has ranged from monarchy to being ruled by the Communist party in 2019. An isolated, agrarian society until the mid-20th century, Nepal entered the modern era in 1951 without schools, hospitals, roads, telecommunications, electric power, industry, or civil service (Economy of Nepal, 2020). The country has, however, made progress toward sustainable economic growth since the 1950s and 
opened the country to economic liberalization leading to economic growth and improvement in living standards than compared to the past. The biggest challenges faced by the country in achieving higher economic development are the frequent changes in political leadership as well as corruption.

\section{Focus of the Study}

Several tools and procedures are available for assessing the tax revenue productivity and its contribution to the economy. This study has mainly focused on the implementation and effectiveness of tax in economic development at aggregate levels. It is also considered that there are other intervening variables which are also affecting economic development. In the context of an acute resource gap in the country, the question of resource mobilization is in challenging proposition. In this regard, the tax revenue may be an effective instrument for mobilizing internal resources

\section{Research Questions}

The study has sought to answer the following research questions.

- What is the tax revenue productivity and elasticity?

- What is the impact of tax revenue collection on overall economic development?

\section{Limitations of the Study}

This study is, therefore, primarily based on the secondary data. The secondary data covers the twenty years of its implementation from 1999/2000 to 2018/19. The findings and conclusion of the study are subject to the following limitations:

- The dearth of literature on contribution of tax revenue on national economy has been a notable limitation for this study.

- The results of this study are only the indication of the present tax system in Nepal.

- There may be some inherent limitations of secondary data collected and used in the study.

\section{Literature Review}

Economic theory suggests about the relationship between economic growth and tax revenue. Todaro and Smith (2006) describe economic growth as "the steady process by which the productive capacity of the economy is increased over time to bring about rising levels of national output and income." The growth rate is affected by macro-economic policies, such as taxation, exchange rate, market capitalization money supply and government spending. A tax is a compulsory payment from firms and household to the government (Goode, 1984). Every tax must be based on a valid statute. If there is no valid statute, no legitimate tax can be imposed (Okafor, 2012). It is a financial charge or other levy imposed upon a taxpayer. Tax policy refers 
to the choice by a government as to what amounts and on whom tax is to be levied. Tax policies implemented for a variety of reasons, the key objectives, including a source of revenue generation for financing government spending, resource allocation, re-distribution of income and reducing inequalities arising from the distribution of wealth among consumers. Also, Romer and Romer (2010) remarked that tax policies are implemented either to: finance a budget deficit and counter other influences in the economy. In both developed and developing economies, the government has to play an active role in achieving economic growth (Edame \& Okoi, 2014). In this sense, fiscal policy is an essential vital instrument of government in promoting economic growth. Many economists believe that tax revenue is one of the most significant factors that contribute to a country's growth (Myles, 2000). It has provided developing countries with a stable and predictable fiscal environment to promote growth and to finance their social and physical infrastructural needs. Garba (2014) observed that a country's tax system is a major determinant of other macroeconomic indexes.

\section{Methods and Materials}

\section{Research Design}

To examine the relationship between tax revenue and economic growth proxies by GDP in aggregate level, the study employs explanatory research design considering tax revenue as independent variable and GDP as the dependent variable in aggregate level, along with exchange rate, market capitalization, money supply (M1, M2), and government spending as intervening variables.

\section{Population and Sample}

The quantitative data used in the study have been collected from the Economic Survey published annually by MOF, Annual Reports of IRD, annual customs statistics, various publications of NRB and CBS, and other published sources. Thus, the study analyses the time series data from 1999/200 to 2018/19. Therefore, the study has covered a period of 20 years period, time series data over the study period is collected for the study. The values of all variables are converted into real price (constant price) by GDP deflator. Particularly, real GDP, real tax revenue, real money supply, real market capitalization, and real exchange rate are calculated as nominal exchange rate (i.e. NPR to USD) multiplied by GDP deflator or CPI of USD divided by CPI of Nepal (i.e. base year 2013/14=100) over 20 years period. The GDP deflator and CPI year 2013/14 has been assumed equivalent to the base year 2013/14 according to Nepalese fiscal year.

\section{Nature and Sources of Data}

The simple linear model has been converted into natural log linear model. In order for the specification of a model of cointegrated regression model with a time series data of the variables are employed for the study period of 20 years from 1999/2000 to 2018/19. 


\section{Instruments}

In the process of using and testing the relationship between tax revenue and GDP with other intervening variables, error correction model (ECM) is used. Various other tests such as unit root test, DF and ADF, autocorrelation, partial correlation, correlogram test, Durbin Watson, HDW, Jarque-bera normality test, serial correlation test, heteroscedasticity, Glejser test, specification test, test of Exogeneity, structural break test, multicollinearity test, Ramsey test and Chow-test have also been used to justify the model.

\section{Hypothesis}

$\mathrm{H}_{1}$ : Tax revenue has significant impact on GDP at aggregate level with other intervening variables.

\section{Model Specification}

In so doing, it is hypothesized that there is significant positive impact of tax revenue on GDP. Similarly, it is also hypothesized that the intervening variables government spending and money supply have positive relationship, while exchange rate and market capitalization have negative.

\section{Model}

GDP as Dependent, Tax Revenue and Other Intervening Variables as Independent Variables.

In order to examine the impact of tax revenue on national economic development (GDP) as dependent variable, and exchange rate, market capitalization, money supply $\left(\mathrm{M}_{1}\right.$ $\mathrm{M}_{2}$ ), and government spending, the following model has been employed considering tax revenue as independent variable and GDP as dependent and others as intervening variables. The relationship between the variables has been specified as under:

$$
\mathrm{GDP}_{c t}=f\left(\mathrm{TR}_{c t}, \operatorname{Exr}_{c t}, \quad \mathrm{GSPD}_{c t}, \quad \mathrm{MC}_{\mathrm{tc}}, \mathrm{MS}_{c t},\right)
$$

The relationship and impact of tax revenue on GDP has specified as:

$$
\begin{aligned}
& \operatorname{lnGDP}_{c t}=\beta_{0}+\beta_{1} \operatorname{lnTR}_{c t}+\beta_{2} \operatorname{lnEXR}_{c t}+\beta_{3} \mathrm{GSPD}_{\mathrm{ct}}+\beta_{4} \operatorname{lnMC}_{c t}+\beta_{5} \operatorname{lnMS}_{c t}+\ldots \ldots+\mathrm{e}_{i} \ldots \text {.(I) } \\
& \operatorname{lnGDP}_{c t}=\beta_{0}+\beta_{1} \ln \mathrm{TR}_{c t}+\beta_{2} \operatorname{lnEXR}_{c t}+\beta_{3} \mathrm{GSPD}_{\mathrm{ct}}+\beta_{4} \operatorname{lnMC}_{c t}+\ldots \ldots+\mathrm{e}_{i} \ldots \ldots \ldots \ldots \ldots \ldots \text { (II) } \\
& \operatorname{lnGDP}_{c t}=\beta_{0}+\beta_{1} \operatorname{lnTR}_{c t}+\beta_{2} \operatorname{lnEXR}_{c t}+\beta_{3} \ln _{\mathrm{GSPD}}+\beta_{\mathrm{ct}} \operatorname{lng~S}_{c t}+\ldots \ldots \ldots+\mathrm{e}_{i} \ldots \ldots \text { (III) }
\end{aligned}
$$

Where,

In $\mathrm{GDP}_{c t}$, Represents log linear Gross Domestic Products at constant price at time ' $\mathrm{t}$ '.

In $\mathrm{TR}_{c i}$, Represents log linear tax revenue at constant price at time ' $\mathrm{t}$ '.

$\operatorname{lnEXR}_{c t}$, Represents log linear Exchange Rate at constant price at time ' $\mathrm{t}$ '.

ln Cons ${ }_{\mathrm{ct}}$, Represents log linear Consumption at constant price at time ' $\mathrm{t}$ '. 
$\operatorname{lnMC}_{c t}$, Represents log linear Market capitalization at constant price at time, ' $\mathrm{t}$ '.

$\operatorname{lnMS}_{c t}$, Represents log linear Money Supply at constant price at time ' $\mathrm{t}$ '.

\section{Results and Discussion}

Many of the economic variables do not possess the characteristics of stationary, it is necessary to keep in mind the type of data series used in the model. Valid estimation and inference are not possible when a set of non-stationary variables is cointegrated. After the estimation of three different equations to find out appropriate variables for the estimation, an Error Correction Model (ECM) is employed to measure the tax revenue productivity with the use of lagged dependent variable also facilitates to obtain short and long-term effect of tax revenue on the GDP. The first difference data is used for ECM. The cointegration of a set of variables provides sufficient ground for specifying a corresponding error correction or dynamic equation for these variables and is compatible with long-run equilibrium behavior.

\section{Unit Root Test}

A unit root test verifies whether a time series variable is non-stationary using an autoregressive model. A well-known test that is valid in large samples is the augmented Dickey-Fuller test. The optimal finite sample tests for a unit root in autoregressive models are developed. Dickey and Fuller (1979) developed a procedure for testing whether a variable has a unit root or, equivalently, that the variable follows a random walk. Hamilton (1994) described the four different cases to which the augmented Dickey-Fuller test could be applied. In the process of checking whether the variables has a unit root or not. If the absolute test statistics is more than critical value then null hypothesis that the series is non-stationary cannot be accepted. That is the guidelines. However, if the absolute test statistics is less than critical value, null hypothesis can be rejected and the alternative hypothesis will be accepted.

$\mathrm{H}_{0}$ : The variables log linear at constant price has not stationarity or unit root.

$\mathrm{H}_{1}$ : The variable log linear at constant price has stationarity or no unit root.

It is evident from Table: 1 that the variable $\ln G D P_{c t}$ has the p-value that is $0.5581>$ 0.05 so it cannot reject the null hypothesis, meaning that the variable $\ln G D P_{c t}$ at level has a unit root. The test statistics guidelines indicate that if test statistics is more than critical value at $5 \%$, it cannot reject null hypothesis but the test statistics -1.404466 and critical value at $1 \%, 5 \%$ and $10 \%$ is less than the test statistics. So it cannot reject null hypothesis, meaning that $\operatorname{lnGDP_{ct}}$, has a unit root and all the other variables $\ln T R_{c t}, \ln \mathrm{MC}_{c t} \ln \mathrm{EXR}_{c t}$, $\operatorname{lnGSPDs}_{c t}$ and $\operatorname{lnMS} c t$, have the P-value > 0.05, so it cannot reject null hypothesis, meaning that all the variables have a unit root at level. In addition, the coefficient at lag one is also negative i.e. -0.047171 of all the variables, so the model is viable. When the Variables are converted into first difference: After the first differences level of the probability or the p-value 
that is $0.0081<0.05$. So, it can reject the null hypothesis, meaning that $\operatorname{lnGDP}_{c t}$ has no unit root or stationary after the first difference, including all variables in the model.

\section{Table 1}

Dickey Fuller, Augmented Dickey Fuller and Unit Root Test

\begin{tabular}{|c|c|c|c|c|c|c|c|}
\hline \multirow[t]{2}{*}{ Variables } & \multirow[t]{2}{*}{ Test } & \multirow{2}{*}{$\begin{array}{l}\text { Dickey- } \\
\text { fuller }\end{array}$} & \multirow{2}{*}{$\begin{array}{l}\text { Augmented } \\
\text { Dickey- } \\
\text { fuller }\end{array}$} & \multirow{2}{*}{$\begin{array}{c}\mathrm{p}- \\
\text { value }\end{array}$} & \multirow{2}{*}{$\begin{array}{l}\text { Coefficient } \\
\text { At lag }\end{array}$} & \multicolumn{2}{|c|}{ Unit root } \\
\hline & & & & & & t-stat ( ) p & p-value \\
\hline \multirow{4}{*}{$\operatorname{lnGDP}_{c t}$} & At level & -1.9662 & -3.0299 & & & 1.238 & \\
\hline & & $(-3.029)$ & $(-1.4044)$ & 0.5581 & -0.0471 & $(812.40)$ & 0.000 \\
\hline & At first & -1.9628 & -3.0521 & & & 1.6245 & \\
\hline & difference & $(-4.125)$ & $(-3.9937)$ & 0.0076 & -1.4106 & (309.399) & 0.000 \\
\hline \multirow{4}{*}{$\operatorname{lnTR}_{\mathrm{ct}}$} & At level & -187601 & -3.1398 & & & 1.2948 & \\
\hline & & $(-1.3005)$ & $(-2.1243)$ & 0.0311 & -0.01874 & (159.197) & 0.000 \\
\hline & At first & -1.614 & -3.0403 & & & 1.8292 & \\
\hline & difference & $(-3.555)$ & $(-3.4501)$ & 0.0226 & -0.8662 & $(56.0503)$ & 0.000 \\
\hline \multirow{4}{*}{$\operatorname{lnMC}_{c t}$} & At level & -1.9601 & -3.0299 & & & 1.2805 & \\
\hline & & $(-0.5294)$ & $(-0.9999)$ & 0.7312 & 0.0746 & (144.245) & 0.000 \\
\hline & At first & -1.9644 & -3.0655 & & & 1.7718 & \\
\hline & difference & $(-3.7019)$ & $(-3.6319)$ & 0.0174 & -1.3269 & $(51.8051)$ & 0.000 \\
\hline \multirow{4}{*}{$\operatorname{lnGSP} P_{c t}$} & At level & -1.9601 & -3.0299 & & & 1.2857 & \\
\hline & & $(0.3886)$ & $(0.2740)$ & 0.9701 & 0.0140 & (401.905) & 0.000 \\
\hline & At first & -1.9614 & -3.040 & & & 1.7992 & \\
\hline & difference & $(-4.1423)$ & $(-4.0708)$ & 0.0065 & -1.0714 & (143.491) & 0.000 \\
\hline \multirow{4}{*}{$\operatorname{lnEXR} c t$} & At level & -1.9601 & -0.30299 & & & 2.1073 & \\
\hline & & $(-0.5063)$ & $(-0.4639)$ & 0.8783 & -0.0614 & (113.8986) & 0.000 \\
\hline & At first & -1.9614 & -3.0403 & & & -12.910 & \\
\hline & difference & $(-5.4741)$ & $(-5.3507)$ & 0.0005 & -1.2857 & $(-6.2871)$ & 0.000 \\
\hline \multirow{4}{*}{$\operatorname{lnMS}_{c t}$} & At level & $-1.9601(-$ & -3.0299 & & & 1.2420 & \\
\hline & & 1.5863) & $(-1.7535)$ & 0.3903 & -0.2887 & $(375.850)$ & 0.000 \\
\hline & At first & $-1.9614(-$ & -3.0403 & & & 1.6378 & \\
\hline & difference & 6.8129) & $(-6.6097)$ & 0.000 & -1.4639 & (142.2958) & 0.000 \\
\hline
\end{tabular}

Note. Economic Survey, Annual Reports of IRD, NRB and CBS, and researcher calculations. 


\section{Correlogram Test}

A stationary time series is one whose statistical properties such as mean, variance, autocorrelation, etc. are all constant over time. In various times lag the probability value or pvalue $<0.05$ indicates the null hypothesis cannot be rejected, which means that the variables have autocorrelation at level. By checking all the variables including variables $\operatorname{lnGDP}_{c t}, \ln \mathrm{TR}_{c t}, \operatorname{lnEXR} \mathrm{R}_{c t} \operatorname{lnR}_{c t} \operatorname{lnMC} c t$, and $\operatorname{lnMS} \mathrm{S}_{c t}$. In various times lag the probability value or p-value $<0.05$ indicates the null hypothesis cannot be rejected, meaning that the variables have autocorrelation at level. At first difference level correlogram an image of correlation statistics is ups and downs and highs and lows changes indicate very low changes and ups and downs, which means there is no presence of autocorrelation. This randomness is ascertained by computing autocorrelations for data values at varying time lags. In various times lag, the probability value or $\mathrm{p}$-value $>0.05$ indicates the null hypothesis can be rejected which means that the variables have no autocorrelation at first difference level. All the inclusion variables have checked its autocorrelation by using correlogram.

\section{Regression Results: GDP as Dependent, Tax Revenue and other Intervening Variables as Independent Variable.}

The results of regression equations I, II and III specified for economic development as dependent variables and tax revenue as independent variable and other intervening variables. This represents the second model of the specified model. The results are presented in Table: 2

The regression results of all the three different equations provide equation I as an appropriate model. It is because the sign of the coefficient of all the variables are as per the expectations. Moreover, the coefficient of the variable including in the equation I also provides more satisfactory results as compared to rest other two equations II and III. It is also because the coefficient of all the variables is significant. This indicates the inclusion of appropriate and relevant variables in the model.

The regression coefficient also shows the presence of regression as the F-test is significant at more than 98 percent confident limit. Similarly, the coefficient of determination $R^{2}$ is 0.8164 indicating that 81.64 percent of the variations in GDP are explained by the variation of the regressors' included in the model. 
Table 2

Regression of Tax revenue and other intervening variables on GDP

\begin{tabular}{|c|c|c|c|}
\hline Parameters/variables & Equation: I & Equation: II & Equation: III \\
\hline Constant $\left(\beta_{0}\right)$ & $3.76246^{*}$ & $2.63947^{*}$ & $3.6718^{*}$ \\
\hline & [0.19169] & [0.182130] & [0.135467] \\
\hline & $\{13.8358\}$ & $\{14.4728\}$ & $\{20.46051\}$ \\
\hline Tax revenue $\left(\beta_{1}\right)$ & $0.17645^{*}$ & $0.1645^{*}$ & $0.18494^{*}$ \\
\hline & [0.020076] & {$[0.019452]$} & {$[0.019030]$} \\
\hline & $\{5.518759\}$ & $\{5.66393\}$ & $\{5.543649\}$ \\
\hline Exchange rate $\left(\beta_{2}\right)$ & $-0.215490^{*}$ & $-0.23589^{* *}$ & -0.13037 \\
\hline & [0.075067] & [0.072939] & [0.073218] \\
\hline & $\{-1.67171\}$ & $\{-1.726013\}$ & $\{-1.5438\}$ \\
\hline Market Capitalization $\left(\beta_{4}\right)$ & -0.041248 & -0.0432 & \\
\hline & [0.023947] & {$[0.022070]$} & \\
\hline & $\{-0.887275\}$ & $\{-1.10214\}$ & \\
\hline Money Supply $\left(\beta_{5}\right)$ & -0.03270 & & -0.03248 \\
\hline & [0.032744] & & [0.030834] \\
\hline & $\{-0.40524\}$ & & $\{-729081\}$ \\
\hline Government Spending $\left(\beta_{6}\right)$ & $0.081930^{*}$ & $0.30559^{*}$ & $0.451066^{*}$ \\
\hline & {$[0.073197]$} & {$[0.068733]$} & {$[0.0 .05931]$} \\
\hline & $\{7.489262\}$ & $\{7.864639\}$ & $\{8.609383\}$ \\
\hline Adjusted $R^{2}$ & 0.8868 & 0.81465 & 0.80432 \\
\hline Durbin-Watson & 1.7847 & 1.7095 & 1.567 \\
\hline F-statistics & $(268.4874)^{*}$ & $(399.1963)^{*}$ & $(403.0616)^{*}$ \\
\hline Jarque-Bera statistic & 0.4566 & 0.4049 & 0.78013 \\
\hline Breusch-Godfrey LM Observed $R^{2}$ : & 2.768 & 2.3314 & 3.975 \\
\hline$\chi^{2}$ & 0.5667 & 0.326 & 0.406 \\
\hline Breusch- pagon observed: $R^{2}$ : & 5.134 & 9.633 & 8.641 \\
\hline${ }^{2}$ & 5.930 .467 & 0.086 & 0.124 \\
\hline Glejser test Observed: $\boldsymbol{R}^{2}$ : & 1.28 & 6.2179 & 3.806 \\
\hline 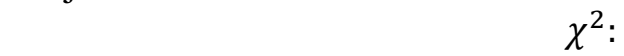 & 0.313 & 0.1835 & 0.577 \\
\hline 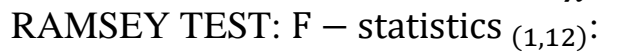 & 2.758 & 1.17677 & 3.959 \\
\hline ARCH $\quad$ Observed: $R^{2}:$ & 1.40785 & 1.5083 & 1.05083 \\
\hline Chow test $\mathrm{F}-$ statistics $_{(7,6)}$ : & $(211.62565)^{*}$ & $(209.3484)$ & $(214.1074)$ \\
\hline
\end{tabular}

Note. Notes. Economic Survey, Annual Reports of IRD, NRB and CBS, and researcher calculations

Figures in parentheses [ ], \{ \} indicates standard error and t-statistics of the concerned variables and p-values.

$\left(^{*}\right)$ Significant at $(0.01) 1 \%$ level

$\left({ }^{* *}\right)$ Significant at $(0.05) 5 \%$ level

$\left(^{* * *}\right)$ Significant at $(0.10) 10 \%$ level 


\section{Durbin Watson Test}

The result of DW test has been reported with the tabulated upper and lower bound of $d$ at 5 percent level. The econometric theory points out that the d-statistics has to lie between $\left(d_{\mathrm{U}}\right)$ and $\left(4-d_{\mathrm{U}}\right)$ to confirm autocorrelation in the model. From the result, it shows that d-statistics $1.7847,1.7095$ and 1.567 lie between upper bound $\left(d_{\mathrm{U}}\right)$ and $\left(4-d_{\mathrm{U}}\right)$ [i.e. $d_{\mathrm{U}}<$ $\left.\mathrm{d}<4-d_{\mathrm{U}}\right]$. Thus, it confirms the absence of auto correlation in the entire model. But the value of DW d statistics lies in indecisive area.

\section{Error Correction Model (ECM)}

From the above three equations I, II and II, the first equation is being employed for the error correction model. The time series data is in the model involves at first difference. The residual of the equation $I$ is taken as independent variable as shown in equation IV as $\left(\mathrm{ECM}_{\mathrm{t}-1}\right)$. Since it is observed that residuals are not normally distributed, autocorrelation and multicollinearity problem in the model, it is necessary to improve the non-normal distribution, autocorrelation and multicollinearity problem in the model. Therefore, the data are transposed into first difference and run the model with error correction model $\left(\mathrm{ECM}_{\mathrm{t}-1}\right)$.

$\Delta\left(\operatorname{lnGDP}_{\mathrm{ct}}\right)=\beta_{0}+\beta_{1} \Delta \operatorname{lnRemit} \mathrm{ct}^{+} \beta_{2} \Delta \operatorname{lnEXR} \mathrm{ct}+\beta_{3} \Delta \operatorname{lnMC}_{\mathrm{ct}}+\beta_{4} \Delta \operatorname{lnMS}_{\mathrm{ct}}+\beta_{5} \Delta \ln \mathrm{GSPD}_{\mathrm{ct}}$ $+\beta_{6} \Delta \operatorname{lnECM} M_{\mathrm{t}-1}+\beta_{7} \Delta \ln G D P \beta_{\mathrm{t}-1}-$ - - (IV)

The use of first difference lagged GDP facilitates to obtain long-run and short run impact of the variable included in the model. The first order condition of econometrics as shown by F-statistics, t-statistics, and $R^{2}$ are satisfactory. The $\mathrm{F}$ value is 8.012796 indicating higher than the table value of $\mathrm{F}$, at 0.01 level. It means the null hypothesis that the elasticity coefficient of tax revenue, exchange rate, market capitalization, money supply and government spending, error and lagged GDP are simultaneously and jointly equals to zero is rejected in favor of the alternative hypothesis they are not equal. The $R^{2}$ shows that the explanatory power of the model is 0.7384 indicating that $73.84 \%$ of the variation of GDP is explained to the extent of 73 percent variation of the independent variable included in the model. 
Table 5

Cointegrated Regression Results

$$
\begin{aligned}
& \Delta\left(\operatorname{lnGDP}_{c t}\right)=\beta_{0}+\beta_{1} \Delta \operatorname{lnTR}_{c t}+\beta_{2} \Delta \operatorname{lnEXR} c t+\beta_{3} \Delta \operatorname{lnMC}_{c t}+\beta_{4} \Delta \operatorname{lnMS}_{c t}+\beta_{5} \Delta \operatorname{lnGSp}_{c t}+ \\
& \beta_{6} \Delta \operatorname{lnECM} \mathrm{t}_{\mathrm{t}-1}+ \\
& \beta_{7} \Delta \ln G D P \beta_{t-1}
\end{aligned}
$$$$
0.0085+0.2116^{*} \Delta \ln T R_{\mathrm{ct}}-0.0305 \Delta \operatorname{lnEXR}_{c t}-0.066^{* * *} \Delta \operatorname{lnMC}_{\mathrm{ct}}+0.056^{* * *} \Delta \operatorname{lnMS}_{c t}
$$$$
\left[\begin{array}{lllll}
0.004017] & {[0.02520]} & {[0.09327]} & {[0.027790]} & {[0.0 .20001]}
\end{array}\right.
$$$$
\{0.186332\} \quad\{1.29894\} \quad\{-0.49184\} \quad\{-0.253441\} \quad\{0.181 .23\}
$$$$
\begin{array}{ccc}
+0.077^{* * *} \ln \Delta \mathrm{GSPDi} & +1.037 \ln \Delta \mathrm{ECM}_{\mathrm{t}-1}-0.0027 \ln \Delta \mathrm{GDP} \beta_{\mathrm{t}-1} \\
{[0.092796]} & {[0.503341]} & {[0.196456]} \\
\{4.065728\} & \{1.845\} & \{0.138900\}
\end{array}
$$

$$
\text { F- } \text { statistics }_{(7,10)}:(8.012796)^{*} \quad \text { Adjusted } R^{2}: 0.7384
$$

Normality test:

Serial correlation test: $\chi^{2}: 0.8422$ )

Heteroskedasticity test: Heteroskedasticity test: Specification test:

Autocorrelation: Structural break test: Multi-collinearity test:

$$
\begin{aligned}
& \text { Jarque-Bera =J-B stat: } 13.2955 \text { (p-value: } 0.001297) \\
& \text { Breusch-Godfrey LM }=\text { Obs. } R^{2}: 2.1875(\mathrm{P}-
\end{aligned}
$$

Note. Researcher calculations

Figures in parentheses [ ], \{ $\}$ indicates standard error and t-statistics of the concerned variables and p-values

$\left(^{*}\right)$ Significant at $(0.01) 1 \%$ level

$\left({ }^{* *}\right)$ Significant at $(0.05) 5 \%$ level

$\left(^{* * *}\right)$ Significant at $(0.10) 10 \%$ level 
The estimated coefficient of remittance in error correction model shows that one percent point rise in remittance has led to 0.2116 percent point increase in real GDP in short run, whereas it is found 0.2944 percent point in the long-run. It means that the short-run marginal productivity of tax revenue is 0.2116 percent point, whereas its long run percent point is 0.2944 .

\section{Conclusion}

The study sought to examine the impact of tax revenue on the economic growth in Nepal during FY1999/2000 and FY2018/2019 using regression analysis. Unit root, cointegration, Correlogram test, Durbin-Watson test, error correction model, and cointegration techniques have been used in the econometric procedure. The results of the study suggest that tax revenue has significant impact on the economic growth both in the short and long run. This implies that the government should develop and implement such policies which could utilize the tax revenue to further the economic development of the country.

\section{Recommendations}

The main challenge is to realize the fact that over dependence on tax revenue is general issues and productive for the economy and even in the Nepalese economy in the long run. In a long run most of the studies reveled that the tax revenue has positive and significant impact on economy. Therefore, we need to devise policies and strategies focused on managing stable tax policy.

\section{References}

Edame, G. E., \& Okoi, W. W. (2014). The impact of taxation on investment and economic development in Nigeria. Academic Journal of Interdisciplinary Studies, 3 (4), 209- 218. https://doi.org/10.5901/ajis.2014.v3n4p209.

Garba, L. S. (2014). Tax revenue and economic growth in Nigeria. (Unpublished Thesis). Zaria: Ahmadu Bello University.

Goode, R. (1984). Government finance in developing countries. Washington D. C. The Brookings Institute.

Hamilton, J. D. (1994). Autoregressive conditional heteroskedasticity and changes in regime. Journal of Econometrics, September/October 1994 (Coathored with Raul Susmel).

Lopez, S., David, J., \& Pau, R. (2007). Government spending and consumption hours preferences. Working Paper, Federal Reserve Board.

Musgrave, R. A., \& Musgrave, P. B. (2004). Public finance in theory and practice. New York: McGraw Hill.

Myles, G. D. (2000). Taxation and economic growth. Fiscal Studies, 21, 141-168. 
Nepal Rastra Bank. (2017). Macro-economic indicator of Nepal. NRB Economic Review, 11, Research Department.

Okafor, R. G. (2012). Tax revenue generation and Nigerian economic development. European Journal of Business and Management, 4(19): 49-56.

Romer, C. D., \& Romer, D. H. (2010). The macroeconomic effects of tax changes: Estimates based on a new measure of fiscal shocks. The American Economic Review, 100, 763801.

Todaro, M. P., \& Smith, S. C. (2006). Economic development. New Jersey: Pearson Addison Wesley.

World Bank. (2003). World development indicator (December, 2003). http://data.worldbank.org/data-catalog/world-development-indicators

World Bank. (2015). World development indicator (December, 2015). http://data.worldbank.org/data-catalog/world-development-indicators.

World Bank. (2016). Fiscal indices studies in developing countries: Survey and Cririque, 21 